\title{
PRESERVATION OF MILKS WITH ADDITION OF ANTIBACTERIAL AND AROMATIC SUPPLEMENTS PRODUCED IN JAPAN
}

\author{
Tatik Khusniati* \\ Microbiology Division, Research Center for Biology, \\ Indonesian Institute of Sciences, Cibinong Science Center, \\ JI Raya Bogor-Jakarta Km 46, Cibinong 16911, Indonesia
}

Received 29 October 2006

\begin{abstract}
The good antibacterial and aromatic supplements produced in Japan for preservation of milks at storage was investigated. Nineteen sweet and herb materials were made juices as supplements to preserve the milks. Bacterial counts, $\mathrm{pH}$, protease activities and lipase activities of supplemented milks, and antibacterial activities of supplements were detected by total plate counts, glass electrode $\mathrm{pH}$ meter, azocasein, modified Dole extraction and turbidity methods. Eleven of nineteen milks added $10 \%$ of honey, garlic, ginger, horseradish, "sansho", "yuzu", green perilla, "nira", green tea, bamboo leaf and "yomogi" were selected as good supplemented milks based on $\mathrm{pH}$ of these milks closed to $\mathrm{pH}$ of milks, the lower bacterial counts, protease activities and lipase activities of these milks than that without supplements, at 5 days before up to 10 days after use by date $(\mathrm{P}<0.05)$, consumed materials and antibacterial activities of these supplements in inhibiting Pseudomonas fluorescens P. 33 in the nutrient media.
\end{abstract}

Keywords: milks, preservation, antibacterial and aromatic supplements, Pseudomonas fluorescens P. 33.

\section{INTRODUCTION}

The main species of Pseudomonas spp. spoiled pasteurized milks was Pseudomonas fluorescens $[9,13,14,22,24]$. It has been reported that pasteurized milks stored at 4.5 and $7^{\circ} \mathrm{C}$ spoiled due to the activities of psychrotrophic bacteria, especially Pswudomonas sp., and the average shelf life or the times started from the time after finishing the pasteurization' process of milks to the time of the use by date, of pasteurized milks at temperature in the range $72^{\circ}$ for $15^{\prime \prime}$ to $88^{\circ} \mathrm{C}$ for 15 ", stored at 4.5 and $7^{\circ} \mathrm{C}$ were around 7 days [6, 9, 13, 14, 21, 24]. However, Heo [20] examined commercial milk samples held at $7.2^{\circ} \mathrm{C}$ and found that after 10 days of storage, $91 \%$ of milks were acceptable, whereas after 14 days, $82 \%$ of whole milks were still acceptable.

The spoilage of pasteurized milks after use by date due to the activities of psychrotrophic bacteria may resulted in the microbial and chemical changes of the milks $[26,31]$ and the volatile compounds of the milks [28, 31]. The biochemical changes of milks at spoilage may resulted from the activities of extracellular enzymes [19, 29], especially protease which degraded protein $[21,23]$ and lipase which degraded lipid $[8,17]$. The spoilage of milks may be

\footnotetext{
* Corresponding author e-mail: tatikkhusni@yahoo.com
} 
reduced by addition of antibacterial and aromatic supplements. The reason why the use Japanese materials in this research was because the Japanese materials which contain antibacterial and aromatic compounds may be good for preservation of pasteurized milks at storage. To know further which materials as good supplements in preservation of pasteurized milks at storage, the selection of the good supplements from the 19 antibacterial and aromatic materials produced in Japan were conducted.

The 19 antibacterial and aromatic materials as mentioned above contain specific antibacterial and aromatic compounds. The sweet material of honey contain antibacterial compouds of "inhibine" and specific honey aromatic compounds $[1,7]$. The roots' materials of ginger contain antibacterial compounds of "gingerin" and specific ginger aromatic compounds [3, 18], and horseradish contain flavour compounds of some glucosinolates in which it has antibacterial activities [16]. The seeds' materials of "yuzu" had yuzu oil as antibacterial materials and linalool \& decanal as specific flavour compounds [25], and "sansho" had specific capsicum volatile compounds which contain antibacterial activities [12]. The bulbs' materials of garlic contain antibacterial compounds of allicin and specific garlic aromatic compounds [5, 30], and "myouga" as Japanese ginger bud may contain specific myouga aromatic compounds which had antibacterial activities. The other some antibacterial and aromatic materials of dried leafs, that are green tea contain polyphenolic compounds as antibacterial and aromatic compounds [3, 4], bamboo leaf as a heteroxylan and hemicellulosic materials may contain specific flavour compounds [32], and "yomogi" as Japanese aromatic materials which had un-identified specific aromatic flavours. The other some Japanese aromatic materials of fresh leafs, that are red perilla contain anthocyanin as aromatic compounds [33]; "green perilla" contain specific bioactive and aromatic compounds [10]; "yakumi negi", "naga-negi" and "nira" contain strongly onion and garlicky flavours; tade had unidentified specific indigenous flavours, mitsuba had specific flavorfull vegetables; "shungiku" and "kiku" (flower).

It may be that there were the effect of antibacterial and aromatic supplements to the preservation of milks, and it is expected that these aromatic supplements can increase quality and self life of pasteurized milks. This papers reports the preservation of milks with addition of those antibacterial and aromatic supplements as mentioned above produced in Japan.

\section{MATERIALS AND METHODS}

\subsection{Milk samples}

Commercial pasteurized milks at $85^{\circ} \mathrm{C}$ for $30^{\prime \prime}$ in $200 \mathrm{ml}$, produced by factory in North Plan Farm in Sapporo - Japan, were purchased. The milk samples were transported on ice to the laboratory and stored at $4^{\circ} \mathrm{C}$ until use by date stamped on the milks' cover which made from carton. At 5 days before use by date, a $100 \mathrm{ml}$ aliquot of each milk sample was transferred aseptically into a $200 \mathrm{ml}$ sterile bottles. The milks' samples were analyzed for total aerobic counts. Each treatment was performed in triplicate.

\subsection{Preparation of antibacterial and aromatic materials}

Japan's antibacterial and aromatic supplements were produced from materials which contain antibacterial and aromatic compounds found from Sapporo-Japan. Nineteen materials used in these treatments were honey (sweet), ginger and horseradish (roots), "yuzu" and "sansho" (seeds), garlic and "myouga" (bulbs), green tea, bamboo leaf and "yomogi" (dried leafs), red perilla, green perilla, "yakumi negi", "naga-negi", "nira", "tade", "mitsuba" and "sungiku" (fresh leafs) and "kiku" (flower). All the materials were homogenized by using blender and the homogenized materials were then filtered by filter which made from stainless steel to produce liquid materials as juice supplements. 
A 50 gram antibacterial and aromatic materials were made juice by adding $500 \mathrm{ml}$ boiled waters. The materials were homogenized by using blender. The juices produced were filtered by stainless steel filter and the cleared juices were kept in the refrigerated temperatures up to ready to be used as supplements.

\subsection{Pasteurised milks with addition of supplements}

One representative of each of nineteen different liquid supplements was added into separate 200 $\mathrm{ml}$ aliquots of the batch pasteurized milks. The samples with addition of the supplements, together with milks without supplements, were incubated at $4^{\circ} \mathrm{C}$ in order to minimize the growth of psychrotrophic bacteria, for up to 15 days ( 5 days before use by date, at use by date, 5 days after use by date, and 10 days after use by date). In every time of storage, all milks' samples were analyzed for total aerobic counts, $\mathrm{pH}$ and used for production of cell-free supernatants to be assayed for protease and lipase activities. The results presented for bacterial counts, $\mathrm{pH}$ and protease and lipase activities are mean values for the three replicates.

\subsection{Total aerobic bacterial counts}

Ten-fold serial dilutions of the milk samples were made and spread plate counts performed according to Australian Standard AS 1766.1.4 using Nutrient Agar. The plates were incubated for 2 - 3 days at $30^{\circ} \mathrm{C}$.

\subsection{The pH of supplemented milks}

The $\mathrm{pH}$ of pasteurized milks with addition of antibacrerial and aromatic compounds at various times of storage was measured by using $\mathrm{pH}$ meter. The $\mathrm{pH}$ of nineteen samples of refrigerated milks with addition of the supplements were measured by $\mathrm{pH}$ meter at various times of storage 5 days before up to 10 days after the use by date.

\subsection{Preparation of cell free extracts}

Bacterial cells were removed from the incubated milks' samples (with and without addition of aromatic supplements) by centrifugation at $24000 \mathrm{~g}$ for 10 minutes at $4^{\circ} \mathrm{C}$. The resulting supernatants were collected and stored at $-20^{\circ} \mathrm{C}$ in sterile bottles until assayed for enzyme activities

\subsection{Protease activity assay}

Proteolytic activity was assayed by the azocasein method, using sulphanilamide-azocasein (Sigma Chemical Co., USA) as the substrate, according to the method of Christen \& Marshall [11], with some modifications. The reaction mixture contained $2 \mathrm{ml}$ of azocasein $(10 \mathrm{~g} / \mathrm{l}$, dissolved by heating $0.1 \mathrm{M}$-Tris- $\mathrm{HCl}$ buffer $\mathrm{pH} 7.4$ (sterile) containing $2 \mathrm{mM}-\mathrm{CaCl}_{2}$ at $63^{\circ} \mathrm{C}$ for 30 minutes) and $0.5 \mathrm{ml}$ enzyme solution (cell free supernatant), and was incubated for $1 \mathrm{~h}$ at $37^{\circ} \mathrm{C}$. One unit of proteolytic activity was defined as the volume of enzyme solution (ml) required to produce an absorbance increase at $345 \mathrm{~nm}$ of 0.01 in hour under the assay conditions.

\subsection{Lipase assay activity}

The lipase assay was based on the assay procedure of Fitz-Gerald \& Deeth [17] and a modified Dole extraction procedure of Deeth et al. [15]. Cell-free culture supernatants (crude enzyme; 0.5 $\mathrm{ml}$ ), $0.25 \mathrm{ml}$ buffer (2 M-diethanolamine-HCL, pH 8.5), $3 \mathrm{ml}$ UHT cream, and $1 \mathrm{ml}$ sterile 
water (in a stoppered test tube) were incubated at $40^{\circ} \mathrm{C}$ for 2 hours in a shaking (100 rpm) waterbath. To the reaction mixture was added $10 \mathrm{ml}$ of extraction mixture (isopropanol: petroleum ether: $\left.4 \mathrm{~N} \mathrm{H}_{2} \mathrm{SO}_{4}\right)(40: 10: 1), 6 \mathrm{ml}$ petroleum ether, and $4 \mathrm{ml}$ water. The mixture was shaken for 15 seconds, and an-aliquot $(8 \mathrm{ml})$ of the upper layer was transferred to a $50 \mathrm{ml}$ conical flask and $0.5 \mathrm{ml}$ of $0.02 \%$ bromothymol blue indicator was added. The free fatty acid (F.F.A) titrated with $0.02 \mathrm{~N}$ methanolic $\mathrm{KOH}$. The activities of the cell-free supernatans are expressed as $\mu$ equiv.ml ${ }^{1} \mathrm{~h}^{-1}$ using the fomula, as follow:

$$
\frac{N\left(T_{\text {test }} / P_{\text {test }}-T_{\text {control }} / P_{\text {control }}\right) \times 10^{3}}{V \times H}
$$

where $\mathrm{N}$ is the normality of the methanolic $\mathrm{KOH}, \mathrm{T}_{\text {test }}$ and $\mathrm{T}_{\text {control }}$ are the titration volumes for the test and the control respectively, $\mathrm{P}_{\text {test }}$ and $\mathrm{P}_{\text {control }}$ are the proportions of the upper layers titrated, $\mathrm{V}$ is the volume of enzyme solution and $\mathrm{H}$ is the incubation time in hours.

\subsection{Antibacterial activities' detection}

Detection of antibacterial activities of aromatic supplements in inhibiting Ps. fluorescens P. 33 were conducted by using "Turbidity" method. The Ps. fluorescens P.33 were found from Culture Collection of Dairy Science Laboratoray, Hokkaido University, Japan. The media used for the growth of Ps. fluorescens P33 was YPD liquid media. The amount of $0.1 \mathrm{ml}$ of Ps. fluorescens P33 were poured in the $9 \mathrm{ml}$ liquid media and $1 \mathrm{ml}$ of every supplement from 11 aromatic milks' supplements were added into the inoculated media. The media which contain both Ps. fluorescens P 33 and every aromatic milks' supplement were then incubated at $25^{\circ} \mathrm{C}$. After incubation for 1 day, the turbidity (OD) were measured by using spectrophotometer with $\lambda$ $660 \mathrm{~nm}$. The comparison between OD of the inoculated media with addition of every aromatic milks' supplement and OD of control (the inoculated media without milks' supplements) showed the antibacterial activities of the milks' supplements in suppressing the growth of Ps. fluorescens $\mathrm{P} 33$.

\subsection{Statistical analysis}

All treatments were statistically analyzed by ANOVA with Factorial Complete Randomized Design 27 using General Linear Model with three replications.

\section{RESULTS}

Total bacterial counts of milks with addition of antibacterial and aromatic supplements at various times of storage were shown in Table 1. The preservation of the milks can be largely explained by lower total bacterial counts caused by lower production of psychotrophic bacteria in this milk. The total bacterial counts in supplemented milks were significantly lower than that without supplements at various times of storage $(\mathrm{P}<0.05)$, and the longer the time of storage, the higher the total bacterial counts of supplemented milks. The total bacterial counts of the supplemented milks at storage 5 days before up to 10 days after use by date were in the range 0 $-2.0 \times 10^{4} \mathrm{cfu} / \mathrm{ml}$, while the total bacterial counts of milks without supplements were in the range $1 \times 10^{2}-7.4 \times 10^{4} \mathrm{cfu} / \mathrm{ml}$ at the same times of storage.

From the nineteen supplemented milks with addition of aromatic supplements, the eleven supplemented milks with addition of honey, ginger, horseradish, "yuzu", "sansho", garlic, green tea, bamboo leaf, "yomogi", green perilla and "nira" were selected as good supplemented milks. The selection in the nine of the eleven supplemented milks with addition of honey, ginger, horseradish, "yuzu", "sansho", garlic, green perilla and "nira" were based on the lower bacterial counts of these nine supplemented milks than that without supplements at various times of 
storage. Furthermore, the selection in the three of the eleven supplemented milks with addition of green tea, bamboo leaf and "yomogi" were based on the lower bacterial counts of these three milks than that without supplements at various times of storage, and this selection were also based on the consumed materials in Japan. The materials of bamboo leaf and "yomogi" in dried package were consumed as beverage' supplements, while dried green tea was consumed as materials for tea beverage. The total bacterial counts of the nine supplemented milks were 0 $\mathrm{cfu} / \mathrm{ml}$ (at use by date) and $1-7 \times 10^{2} \mathrm{cfu} / \mathrm{ml}$ (at 10 days after use by date), and the total bacterial counts of the three supplemented milks were $2-3 \times 10^{2} \mathrm{cfu} / \mathrm{ml}$ (at use by date) and $1.1-1.8 \times 10^{3}$ (at 10 days after use by date).

Table 1: Total bacterial counts of milks with addition of antibacterial and aromatic supplements at various times of storage $(\mathrm{cfu} / \mathrm{ml})$.

\begin{tabular}{|c|c|c|c|c|c|}
\hline No. & $\begin{array}{l}\text { Antibacterial } \\
\text { and aromatic } \\
\text { supplements }\end{array}$ & $\begin{array}{l}5 \text { days } \\
\text { before use } \\
\text { by date }\end{array}$ & at use by date & $\begin{array}{l}5 \text { days after } \\
\text { use by date }\end{array}$ & $\begin{array}{l}10 \text { days after } \\
\text { use by date }\end{array}$ \\
\hline 1 & milks (control) & $1 \times 10^{2}(\mathrm{de})$ & $3.4 \times 10^{3}(\mathrm{c})$ & $3.2 \times 10^{4}(\mathrm{~b})$ & $7.4 \times 10^{4}$ (a) \\
\hline 2 & honey & $0(\mathrm{p})$ & $0(\mathrm{p})$ & $0(\mathrm{p})$ & $1.0 \times 10^{2}(\mathrm{o})$ \\
\hline 3 & ginger & $0(\mathrm{p})$ & $0(\mathrm{p})$ & $0(\mathrm{p})$ & $3 \times 10^{2}(\mathrm{lmn})$ \\
\hline 4 & horseradish & $0(\mathrm{p})$ & $0(\mathrm{p})$ & $2 \times 10^{2}(\mathrm{n})$ & $4 \times 10^{2}(\mathrm{klmj})$ \\
\hline 5 & "yuzu” & $0(\mathrm{p})$ & $0(\mathrm{p})$ & $3 \times 10^{2}(\mathrm{lmn})$ & $5 \times 10^{2}($ hijkl) \\
\hline 6 & "sansho" & $0(\mathrm{p})$ & $0(\mathrm{p})$ & $2 \times 10^{2}(\mathrm{n})$ & $3 \times 10^{2}(\mathrm{mn})$ \\
\hline 7 & garlic & $0(\mathrm{p})$ & $0(\mathrm{p})$ & $2 \times 10^{2}$ (no) & $5 \times 10^{2}(\mathrm{hijkl})$ \\
\hline 8 & "myouga" & $0(\mathrm{p})$ & $6 \times 10^{2}(\mathrm{hijk})$ & $2.1 \times 10^{3}(\mathrm{de})$ & $5.4 \times 10^{3}(\mathrm{c})$ \\
\hline 9 & green tea & $0(\mathrm{p})$ & $2 \times 10^{2}(\mathrm{n})$ & $3 \times 10^{2}(\mathrm{mn})$ & $1.7 \times 10^{3}(\mathrm{ef})$ \\
\hline 10 & bamboo leaf & $0(\mathrm{p})$ & $3 \times 10^{2}(\mathrm{lmn})$ & $4 \times 10^{2}(\mathrm{klmj})$ & $1.8 \times 10^{3}(\mathrm{ef})$ \\
\hline 11 & "yomogi” & $0(\mathrm{p})$ & $2 \times 10^{2}(\mathrm{n})$ & $3 \times 10^{2}(\mathrm{lmn})$ & $1.1 \times 10^{3}(\mathrm{fg})$ \\
\hline 12 & red perilla & $0(\mathrm{p})$ & $2 \times 10^{2}(\mathrm{no})$ & $6 \times 10^{2}(\mathrm{hijk})$ & $1.6 \times 10^{3}(\mathrm{ef})$ \\
\hline 13 & green perilla & $0(\mathrm{p})$ & $0(\mathrm{p})$ & $3 \times 10^{2}(\mathrm{lmn})$ & $7 \times 10^{2}($ ghijk $)$ \\
\hline 14 & “yakumi negi” & $0(\mathrm{p})$ & $2 \times 10^{2}(\mathrm{n})$ & $4 \times 10^{2}(\mathrm{klmj})$ & $6 \times 10^{2}(\mathrm{hijk})$ \\
\hline 15 & “naga negi” & $0(\mathrm{p})$ & $5 \times 10^{2}($ hijk $)$ & $9 \times 10^{2}(\mathrm{ghi})$ & $3.2 \times 10^{3}(\mathrm{~cd})$ \\
\hline 16 & “ nira" & $0(\mathrm{p})$ & $0(\mathrm{p})$ & $3 \times 10^{2}(\mathrm{lmn})$ & $6 \times 10^{2}(\mathrm{hijk})$ \\
\hline 17 & "tade" & $0(\mathrm{p})$ & $8 \times 10^{2}(\mathrm{gh})$ & $5.2 \times 10^{3}(\mathrm{c})$ & $2.0 \times 10^{4}(\mathrm{~b})$ \\
\hline 18 & “mitsuba" & $0(\mathrm{p})$ & $3 \times 10^{2}(\mathrm{lmn})$ & $5 \times 10^{2} \quad(\mathrm{ijklm})$ & $2.4 \times 10^{3}(\mathrm{de})$ \\
\hline 19 & "shungiku" & $0(\mathrm{p})$ & $4 \times 10^{2}(\mathrm{klmj})$ & $7 \times 10^{2}$ (ghij) & $2.6 \times 10^{3}(\mathrm{de})$ \\
\hline 20 & "kiku" & $0(\mathrm{p})$ & $4 \times 10^{2}(\mathrm{klm})$ & $6 \times 10^{2}(\mathrm{hijk})$ & $2.5 \times 10^{3}(\mathrm{de})$ \\
\hline
\end{tabular}

Note: The different one of the letters shows significantly different $(\mathrm{P}<0.05)$, " ": Japan's antibacterial and aromatic supplements names.

The $\mathrm{pH}$ of the eleven milks with addition of antibacterial and aromatic supplements at various times of storage was shown in Table 2. The $\mathrm{pH}$ of the eleven supplemented milks with addition of honey, ginger, horseradish, "yuzu", "sansho", garlic, green tea, bamboo leaf, "yomogi", green perilla and "nira" at 5 days before up to 10 days after use by date were in the range $6.69-6.90$, 
while the $\mathrm{pH}$ of milks without supplements were in the range 6.76 - 6.83. In general, there were no significantly different in the $\mathrm{pH}$ of each supplement from all eleven supplements at times of storage, but, there were significantly different in the $\mathrm{pH}$ between some supplemented milks and milks without supplements (control) at the times of storage $(\mathrm{P}<0.05)$. However, all the $\mathrm{pH}$ of some supplemented milks which significantly different with milks without supplements at the times of storage were in the range of $\mathrm{pH}$ which closed in the $\mathrm{pH}$ of milks.

Table 2: The $p H$ of the eleven milks with addition of antibacterial and aromatic supplements at various times of storage.

\begin{tabular}{llllll}
\hline No & $\begin{array}{l}\text { Antibacterial } \\
\text { and aromatic } \\
\text { supplements }\end{array}$ & $\begin{array}{l}\mathbf{5} \text { days before } \\
\text { use by date }\end{array}$ & $\begin{array}{l}\text { at use by } \\
\text { date }\end{array}$ & $\begin{array}{l}\mathbf{5} \text { days after } \\
\text { use by date }\end{array}$ & $\begin{array}{l}\text { 10 days after } \\
\text { use by date }\end{array}$ \\
\hline 1 & milks (control) & $6.76(\mathrm{ijklm})$ & $6.83(\mathrm{cdef})$ & $6.80(\mathrm{efghi})$ & $6.81(\mathrm{defgh})$ \\
2 & honey & $6.73(\mathrm{~lm})$ & $6.90(\mathrm{a})$ & $6.89(\mathrm{ab})$ & $6.90(\mathrm{a})$ \\
3 & ginger & $6.69(\mathrm{n})$ & $6.89(\mathrm{ab})$ & $6.90(\mathrm{a})$ & $6.72(\mathrm{mn})$ \\
4 & horseradish & $6.75(\mathrm{jklm})$ & $6.88(\mathrm{ab})$ & $6.84(\mathrm{cde})$ & $6.83(\mathrm{cdef})$ \\
5 & "yuzu" & $6.76(\mathrm{ijklm})$ & $6.77(\mathrm{hijkl})$ & $6.75(\mathrm{jklm})$ & $6.80(\mathrm{efghi})$ \\
6 & “sansho" & $6.75(\mathrm{jklm})$ & $6.79(\mathrm{fghij})$ & $6.76(\mathrm{ijklm})$ & $6.78(\mathrm{ghijk})$ \\
7 & garlic & $6.76(\mathrm{ijklm})$ & $6.88(\mathrm{bcd})$ & $6.90(\mathrm{a})$ & $6.83(\mathrm{cdef})$ \\
8 & green tea & $6.76(\mathrm{ijklm})$ & $6.89(\mathrm{ab})$ & $6.89(\mathrm{ab})$ & $6.84(\mathrm{efgh})$ \\
9 & bamboo leaf & $6.74(\mathrm{klm})$ & $6.86(\mathrm{bcd})$ & $6.78(\mathrm{ghijk})$ & $6.73(\mathrm{~lm})$ \\
10 & "yomogi" & $6.79(\mathrm{fghij})$ & $6.80(\mathrm{efghi})$ & $6.79(\mathrm{fghij})$ & $6.80(\mathrm{efghi})$ \\
11 & green perilla & $6.81(\mathrm{defgh})$ & $6.85(\mathrm{bcd})$ & $6.79(\mathrm{fghij})$ & $6.82(\mathrm{cdefg})$ \\
12 & "nira" & $6.81(\mathrm{defgh})$ & $6.83(\mathrm{cdefg})$ & $6.82(\mathrm{ghijk})$ & $6.80(\mathrm{efghi})$ \\
\hline
\end{tabular}

Note: The different one of the letters shows significantly different $(\mathrm{P}<0.05)$.

Table 3: Protease activities of the eleven milks with addition of antibacterial and aromatic supplements at various times of storage $(U / m l)$.

\begin{tabular}{llllll}
\hline No. & $\begin{array}{l}\text { Antibacterial } \\
\text { and aromatic } \\
\text { supplements }\end{array}$ & $\begin{array}{l}\mathbf{5} \text { days before } \\
\text { use by date }\end{array}$ & $\begin{array}{l}\text { at use by } \\
\text { date }\end{array}$ & $\begin{array}{l}\mathbf{5} \text { days after } \\
\text { use by date }\end{array}$ & $\begin{array}{l}\text { 10 days after } \\
\text { use by date }\end{array}$ \\
\hline 1 & milks (control) & $0(\mathrm{~h})$ & $0.40(\mathrm{c})$ & $0.50(\mathrm{~b})$ & $0.60(\mathrm{a})$ \\
2 & honey & $0(\mathrm{~h})$ & $0(\mathrm{~h})$ & $0(\mathrm{~h})$ & $0.20(\mathrm{~g})$ \\
3 & ginger & $0(\mathrm{~h})$ & $0(\mathrm{~h})$ & $0(\mathrm{~h})$ & $0.20(\mathrm{~g})$ \\
4 & horseradish & $0(\mathrm{~h})$ & $0(\mathrm{~h})$ & $0.20(\mathrm{~g})$ & $0.30(\mathrm{e})$ \\
5 & "yuzu" & $0(\mathrm{~h})$ & $0(\mathrm{~h})$ & $0.25(\mathrm{f})$ & $0.30(\mathrm{e})$ \\
6 & "sansho" & $0(\mathrm{~h})$ & $0(\mathrm{~h})$ & $0.20(\mathrm{~g})$ & $0.25(\mathrm{f})$ \\
7 & garlic & $0(\mathrm{~h})$ & $0(\mathrm{~h})$ & $0.25(\mathrm{f})$ & $0.30(\mathrm{e})$ \\
8 & green tea & $0(\mathrm{~h})$ & $0.20(\mathrm{~g})$ & $0.30(\mathrm{e})$ & $0.35(\mathrm{~d})$ \\
9 & bamboo leaf & $0(\mathrm{~h})$ & $0.20(\mathrm{~g})$ & $0.30(\mathrm{e})$ & $0.35(\mathrm{~d})$ \\
10 & "yomogi" & $0(\mathrm{~h})$ & $0(\mathrm{~h})$ & $0.25(\mathrm{f})$ & $0.30(\mathrm{e})$ \\
11 & green perilla & $0(\mathrm{~h})$ & $0(\mathrm{~h})$ & $0.25(\mathrm{f})$ & $0.35(\mathrm{~d})$ \\
12 & "nira" & $0(\mathrm{~h})$ & $0(\mathrm{~h})$ & $0.25(\mathrm{f})$ & $0.35(\mathrm{~d})$ \\
\hline
\end{tabular}

Note: The different one of the letters shows significantly different $(\mathrm{P}<0.05)$. 
The protease activities of the eleven milks with addition of antibacterial and aromatic supplements at various times of storage were shown in Table 3. The preservation of the milks can be largely explained by lower proteolysis in supplemented milks than that without supplements caused by lower production of psychotrophic bacteria in this milk. The protease activities of the eleven milks with addition of honey, ginger, horseradish, "yuzu", "sansho", garlic, green tea, bamboo leaf, "yomogi", green perilla and "nira" at 5 days before up to 10 days after use by date, were significantly lower than that without supplements at the same times of storage $(\mathrm{P}<0.05)$, and the longer the time of storage, the higher the protease activities of supplemented milks. The protease activities of the eleven milks at storage 5 days before up to 10 days after use by date were in the range $0-0.35 \mathrm{U} / \mathrm{ml}$, while the protease activities of milks without supplements were in the range $0-0.60 \mathrm{U} / \mathrm{ml}$ at the same times of storage. So, these eleven milks were good supplemented milks based on not only the lower total bacterial counts, but also the lower protease activities of these supplemented milks than that without supplements.

Table 4: Lipase activities of of the eleven milks with addition of antibacterial and aromatic supplements at various times of storage ( $\mu$ equiv. $\mathrm{mL}^{-1} h^{-1}$ ).

\begin{tabular}{llllll}
\hline No. & $\begin{array}{l}\text { Antibacterial } \\
\text { and aromatic } \\
\text { supplements }\end{array}$ & $\begin{array}{l}\mathbf{5} \text { days before } \\
\text { use by date }\end{array}$ & at use by date & $\begin{array}{l}\mathbf{5} \text { days after } \\
\text { use by date }\end{array}$ & $\begin{array}{l}\text { 10 days after } \\
\text { use by date }\end{array}$ \\
\hline 1 & milks (control) & $0(\mathrm{~h})$ & $0.20(\mathrm{~b})$ & $0.28(\mathrm{a})$ & $0.30(\mathrm{a})$ \\
2 & honey & $0(\mathrm{~h})$ & $0(\mathrm{~h})$ & $0(\mathrm{~h})$ & $0.10(\mathrm{~g})$ \\
3 & ginger & $0(\mathrm{~h})$ & $0(\mathrm{~h})$ & $0(\mathrm{~h})$ & $0.10(\mathrm{~g})$ \\
4 & horseradish & $0(\mathrm{~h})$ & $0(\mathrm{~h})$ & $0.10(\mathrm{~g})$ & $0.15(\mathrm{de})$ \\
5 & "yuzu" & $0(\mathrm{~h})$ & $0(\mathrm{~h})$ & $0.12(\mathrm{fg})$ & $0.17(\mathrm{~cd})$ \\
6 & "sansho" & $0(\mathrm{~h})$ & $0.10(\mathrm{~g})$ & $0.10(\mathrm{~g})$ & $0.16(\mathrm{cde})$ \\
7 & garlic & $0(\mathrm{~h})$ & $0(\mathrm{~h})$ & $0.10(\mathrm{~g})$ & $0.15(\mathrm{de})$ \\
8 & green tea & $0(\mathrm{~h})$ & $0.15(\mathrm{de})$ & $0.18(\mathrm{bc})$ & $0.20(\mathrm{~b})$ \\
9 & bamboo leaf & $0(\mathrm{~h})$ & $0.16(\mathrm{cde})$ & $0.18(\mathrm{bc})$ & $0.20(\mathrm{~b})$ \\
10 & "yomogi” & $0(\mathrm{~h})$ & $0(\mathrm{~h})$ & $0.15(\mathrm{de})$ & $0.17(\mathrm{~cd})$ \\
11 & green perilla & $0(\mathrm{~h})$ & $0(\mathrm{~h})$ & $0.14(\mathrm{ef})$ & $0.17(\mathrm{~cd})$ \\
12 & “nira" & $0(\mathrm{~h})$ & $0(\mathrm{~h})$ & $0.16(\mathrm{cde})$ & $0.19(\mathrm{bc})$ \\
\hline
\end{tabular}

Note: The different one of the letters shows significantly different $(\mathrm{P}<0.05)$

The lipase activities of the eleven milks with addition of antibacterial and aromatic supplements at various times of storage were shown in Table 4 . The preservation of the milks can be largely explained by lower lipolysis in supplemented milks than that without supplements caused by lower production of psychotrophic bacteria in this milk. The lipase activities of the eleven milks with addition of honey, ginger, horseradish, "yuzu", "sansho", garlic, green tea, bamboo leaf, "yomogi", green perilla and "nira" at 5 days before up to 10 days after use by date, were significantly lower than that without supplements at the same times of storage $(\mathrm{P}<0.05)$, and the longer the time of storage, the higher the lipase activities of supplemented milks. The lipase activities of the eleven milks at storage 5 days before up to 10 days after use by date, were in the range $0-0.20 \mu$ equiv. $\mathrm{ml}^{-1} \mathrm{~h}^{-1}$, while the lipase activities of milks without supplements were in the range $0-0.30 \mu$ equiv. $\mathrm{ml}^{-1} \mathrm{~h}^{-1}$ at the same times of storage. So, these eleven milks were 
good supplemented milks based on not only the lower total bacterial counts and protease activities, but also the lower lipase activities of these supplemented milks than that without supplements.

Table 5. The original $p H$ values of the eleven juices of the antibacterial and aromatic supplements.

\begin{tabular}{lll}
\hline No. & Suplements' juices & pH \\
\hline 1 & honey ("hashimizu") & $6.10(\mathrm{f})$ \\
2 & "yuzu" & $3.47(\mathrm{j})$ \\
3 & ginger ("shouga") & $6.55(\mathrm{~d})$ \\
4 & horseradish ("wasabi") & $6.56(\mathrm{~d})$ \\
5 & garlic ("ninniku") & $6.64(\mathrm{c})$ \\
6 & pepper ("sansho") & $5.16(\mathrm{i})$ \\
7 & green tea ("ocha") & $5.85(\mathrm{~g})$ \\
8 & bamboo leaf ("saza") & $6.78(\mathrm{a})$ \\
9 & "nira” & $6.36(\mathrm{e})$ \\
10 & "yomogi” & $5.81(\mathrm{~h})$ \\
11 & green perilla & $6.75(\mathrm{~b})$ \\
\hline
\end{tabular}

Note: The different letters show significantly different $(\mathrm{P}<0.05)$.

Table 6: The supernatans produced (ml/1l juice) from the eleven $10 \%$ milks' supplements $(w / v)$.

\begin{tabular}{lll}
\hline No. & Milks' supplements & $\begin{array}{c}\text { Supernatans produced } \\
\text { (ml/1 1 l juice*) }\end{array}$ \\
\hline 1 & honey ("hashimizu") & $1000(\mathrm{a})$ \\
2 & "yuzu" & $950(\mathrm{~b})$ \\
3 & ginger ("shouga") & $945(\mathrm{~b})$ \\
4 & horseradish ("wasabi") & $870(\mathrm{c})$ \\
5 & garlic ("ninniku") & $960(\mathrm{~b})$ \\
6 & pepper ("sansho") & $860(\mathrm{c})$ \\
7 & green tea ("ocha") & $780(\mathrm{~d})$ \\
8 & bamboo leaf ("saza") & $940(\mathrm{~b})$ \\
9 & "nira” & $940(\mathrm{~b})$ \\
10 & "yomogi" & $780(\mathrm{~d})$ \\
11 & green perilla & $960(\mathrm{~b})$ \\
\hline
\end{tabular}

Note: The different letters show significantly different $(\mathrm{P}<0.05)$, *Juice was extracted from every supplement of eleven aromatic supplements.

The original $\mathrm{pH}$ values of the eleven juices of the antibacterial and aromatic milks' supplements were shown in Table 5. There were the differences in the $\mathrm{pH}$ values between eleven milks' 8 
supplements, with the highest $\mathrm{pH}$ in milks' supplements was bamboo leaf (6.78), while the lowest $\mathrm{pH}$ was yuzu $(3.47)(\mathrm{P}<0.05)$. The $\mathrm{pH}$ values of the other milks' supplements of honey, ginger, horseradish, garlic, "nira", green perilla were in the range $6.10-6.75$; while the $\mathrm{pH}$ values of the other milks" supplements of "sansho", green tea and "yomogi" were in the range 5.16 - 5.85. Furthermore, the supernatans produced from the eleven supplements' juices were shown in Table 6 . The highest production of the supernatans from the eleven supplements was honey $(1000 \mathrm{ml})$, while the lowest production of the supernatans were green tea and yomogi $(780 \mathrm{ml})$, respectively $(\mathrm{P}<0.05)$. The other supernatans produced from milks' supplements of "yuzu", ginger, garlic, bamboo leaf, "nira" and green perilla were in the range $940-960 \mathrm{ml}$, while the production of the other supernatans from horseradish and "sansho" were in the range $860-870 \mathrm{ml}$.

Table 7. Antibacterial activities (OD) in supernatans of milks' supplements in inhibiting Pseudomonas fluorescens P33.

\begin{tabular}{|c|c|c|c|c|}
\hline \multirow{2}{*}{ No. } & \multirow{2}{*}{$\begin{array}{l}\text { Supernatans of milks' } \\
\text { supplements }\end{array}$} & \multicolumn{3}{|c|}{ Pseudomonas fluorescens } \\
\hline & & (OD:0.5) & (OD:0.3) & (OD:0.1) \\
\hline 1 & honey (“hachimitsu”) & $0.220(\mathrm{~cd})$ & $0.180(\mathrm{gh})$ & 0.140 (mno) \\
\hline 2 & “yuzu” & $0.193(\mathrm{efg})$ & $0.156(\mathrm{klmn})$ & $0.086(q)$ \\
\hline 3 & ginger (“shouga") & $0.243(\mathrm{ab})$ & 0.203 (def) & 0.146 (lmno) \\
\hline 4 & horseradish (“wasabi”) & $0.076(q)$ & $0.103(\mathrm{p})$ & $0.013(\mathrm{r})$ \\
\hline 5 & garlic (“ninniku”) & $0.000(\mathrm{~s})$ & $0.000(\mathrm{~s})$ & $0.000(\mathrm{~s}$ \\
\hline 6 & pepper ("sansho") & $0.244(\mathrm{ab})$ & $0.206(\mathrm{cdef})$ & $0.156(\mathrm{jklm})$ \\
\hline 7 & green tea ("ocha") & $0.241(\mathrm{ab})$ & $0.186(f g)$ & 0.146 (lmno) \\
\hline 8 & bamboo leaf ("sasa”) & $0.226(\mathrm{bc})$ & 0.176 (ghi) & 0.133 (o) \\
\hline 9 & "nira" & $0.226(\mathrm{bc})$ & 0.166 (hijk) & $0.136($ no) \\
\hline 10 & "yomogi" & $0.244(\mathrm{ab})$ & 0.203 (def) & $0.156(\mathrm{jklm})$ \\
\hline 11 & green perilla & $0.220(\mathrm{~cd})$ & $0.203(\mathrm{def})$ & 0.146 (lmno) \\
\hline 12 & $\begin{array}{l}\text { control (without } \\
\text { supplements) }\end{array}$ & $0.250(\mathrm{a})$ & $0.210($ cde $)$ & $0.160(\mathrm{ijkl})$ \\
\hline
\end{tabular}

Note: The different one of the letters show significantly different $(\mathrm{P}<0.05)$, OD: Optical Density.

Antibacterial activities in the supernatans of the eleven milks' supplements in inhibiting Ps. fluorescens $\mathrm{P} 33$ in liquid media were shown in Table 7. The seven supplements from the eleven supplements of honey, "yuzu", horseradish, garlic, bamboo leaf, "nira", green perilla had the antibacterial activities in inhibiting Ps. fluorescens P33 (OD 0.5) $(\mathrm{P}<0.05)$. Furthermore, the seven supplements from the eleven supplements of honey "yuzu", horseradish, garlic, green tea, bamboo leaf, "nira" had antibacterial activities in inhibiting Ps. fluorescens P33 (OD 0.3), and the six supplements of honey, "yuzu", horseradish, garlic, bamboo leaf, "nira" had antibacterial activities in inhibiting Ps. fluorescens P33. (OD 0.1) (P < 0.05).

\section{DISCUSSION}

The lower bacterial counts, proteases and lipases activities of the eleven supplemented milks 
with addition of $10 \%$ of honey, ginger, horseradish, "yuzu", "sansho", garlic, green tea, bamboo leaf, "yomogi", green perilla and "nira", than that of un-supplemented milks at 5 days before up to 10 days after use by date, may be due to these eleven supplements contain more antibacterial compounds which can suppress the bacterial counts, proteases and lipases activities of psychrotrophic bacteria, especially Pseudomonas spp. than that without supplements. The longer the times of storage the higher the total bacterial counts, protease and lipase activities of the eleven milks. This may be due to the longer the times of storage the higher the growth of psychrotrophic bacteria, and the increase the growth of psychrotrophic bacteria may produce the increase protease and lipase activities in the refrigerated milks. The $\mathrm{pH}$ of the eleven milks at various times of storage which closed the $\mathrm{pH}$ of milks may be due to antibacterial activities in the eleven milks which may inhibit the growth of psychrotrophic bacteria. This inhibition may resulted in no degradation of the nutritional compounds of the eleven milks which may affected to the change in the $\mathrm{pH}$ of the milks.

Some reports showed that there were antibacterial and aromatic compounds which inhibited the growth of spoilage bacteria and/or pathogenic bacteria in honey $[1,7]$, ginger $[3,18]$, horseradish [16], "yuzu" [25], "sansho" [12], garlic [5, 30], green tea [3, 4], bamboo leaf [32], green perilla [10], "yomogi" and "nira" which may have unidentified antibacterial and aromatic compounds. These reports supported the results of this research in the effects of the antibacterial activities of these eleven supplements as mentioned above in inhibiting bacterial growth of psychrotrophic bacteria as spoilage bacteria in milks at the times of storage. The inhibition of the bacterial growth of psychrotrophic bacteria in stored milks may resulted in the inhibition of the protease and lipase of these bacteria in the milks. It has been reported that the longer the time of storage may resulted in the higher the total bacterial counts in refrigerated pasteurised milks, and. the longer the time of storage, the higher the growth of psychotrophic bacteria, especially Pseudomonas spp. in refrigerated milks [2, 6, 9, 13, 22, 24]. Furthermore, the longer the times of storage, the higher the protease and lipase activities of Pseudomonas spp. in pasteurized milks at storage [14, 21].

The highest of the original $\mathrm{pH}$ value which occured in bamboo leaf' juice and the lowest of the original $\mathrm{pH}$ value in "yuzu" juice from the eleven juices as milks' supplements may be due to the effects of the lower of organic acids' contents in bamboo leaf than that in "yuzu" fruit to the $\mathrm{pH}$ values of these juices; and the different $\mathrm{pH}$ values between the other juices may be due to the effects of the differences in the organic acids' contents between these materials of the other juices to the $\mathrm{pH}$ values of these juices. It has been known that there were the various acidities of the materials of these juices which may resulted in the different $\mathrm{pH}$ values between the $\mathrm{pH}$ values of these juices. The differences in the $\mathrm{pH}$ values between the eleven juices may affect in the differences in the antibacterial activities of these juice in inhibiting psychrotrophic bacteria in the stored milks.

The highest production of supernatan which occured in honey' juice, and the lowest production of the supernatans in green tea and "yomogi' juices, from the production of all the supernatans in the eleven juices, may be due to the differences in the nutritional compounds between honey, green tea and "yomogi' juices, which may affect to the supernatans produced. The different production of the supernatans in the other juices may be due to the different nutritional compounds and the different antibacterial and aromatic compounds in these juices which may affect in the supernatans produced.

The antibacterial activities in inhibiting Ps. fluorescens P33 in OD 0.5 which occurred in the supernatans of the seven supplements of honey, "yuzu", horseradish, garlic, bamboo leaf, "nira" and green perilla may resulted from the contents of the antibacterial compounds of these seven supplements. Furthermore, the antibacterial activities in inhibiting Ps. fluorescens P33 in OD 0.3 . which occurred in the supernatans of the seven supplements of honey, "yuzu", horseradish, garlic, green tea, bamboo leaf and "nira", and the antibacterial activities in inhibiting Ps. fluorescens P33. in OD 0.1 in the supernatans of the seven supplements of honey, "yuzu", 
horseradish, garlic, green tea, bamboo leaf and "nira" may resulted from the contents of the antibacterial compounds of all these supplements

\section{CONCLUSION}

The good antibacterial and aromatic supplements produced in Japan for preservation of milks at storage was investigated. The eleven of the nineteen milks added $10 \%$ supplements of honey, ginger, horseradish, "yuzu", "sansho", garlic, green perilla, "nira", green tea, bamboo leaf and "yomogi" were selected as good milks based on $\mathrm{pH}$ of these milks closed to $\mathrm{pH}$ of milks,. the lower bacterial counts, protease activities and lipase activities of these milks than that without supplements, at storage 5 days before up to 10 days after use by date $(\mathrm{P}<0.05)$, consumed materials and antibacterial activities of these supplements in inhibiting Pseudomonas fluorescens in the nutrient media.

\section{ACKNOWLEDGEMENT}

The authors wish to acknowledge JSPS-RONPAKU for providing the scholarship.

\section{REFERENCES}

1. Adcok (1962), The effect of catalase on the inhibine and peroxidase values of various honies. J. Apric. Res., 38, pp. 34-37.

2. Allen, J.C., Hewedy, F.M., and Hewedy, M.M. (1989), Effect of storage on pasteurized whole and skimmed milk. Egyption Journal of Dairy Science, 17, pp. 327-336.

3. Alzoreky, N.S. and Nakahara, K. (2003), Antibacterial activity of extracts from some edible plants commonly consumed in Asia. International Journal of Food Microbiology, 80, pp. 223-230.

4. An, B.J., Kwak, J.H., Son, J.H., Park, J.M., Lee, J.Y., Jo, C., and Byun, M.W. (2004), Biological and anti-microbial activity of irradiated green tea polyphenols. Food Chemistry, 88, pp. 549-555.

5. Benkeblia, N. (2004), Antimicrobial activity of essential oil extracts of various onions (Allium cepa) and garlic (Allium sativum). Lebensmittel-Wissenschaft und-Technologie, 37, pp. 263-268.

6. Bishop, J.R. and White, C.H. (1986), Assessment of dairy product quality and potential shelf life: a-review. Journal of Food Protection, 49, pp. 739-753.

7. Bogdanox, S. (1997), Nature and Origin of the Antibacterial Substances in Honey. Lebensin-Wiss-u-Technol, 30, pp. 748-753.

8. Bucky, A.R., Hayes, P.R., and Robinson, D.S. (1986), Lipase production by a strain of Pseudomonas fluorescens in whole milk and skimmed milk. Food Microbiology, 3, pp. 3744.

9. Chandler, R.E., Ng, S.Y., and Hull, R.R. (1990), Bacterial spoilage of specialty pasteurized milk products. CSIRO Food Research Quarterly, 50, pp. 11-14.

10. Chen, J.H., Xia, Z.H, and. Tan R.X. (2003), High-performance liquid chromatographic analysis of bioactive triterpenes in Perilla frutescens. Journal of Pharmaceatical Biotechnology, 32, pp. 1175-1179. 
11. Christen, G.H. and Marshall, R.T. (1984), Selected properties of lipase and protease of Pseudomonas fluorescens 27 produced in four media. Journal of Dairy Research, 67, pp. 1680-1687.

12. Cichewicz, R.H. and Thorpe, P.A. (1996), The antimicrobial properties of chile peppers (Capsicum species) and their uses in Mayan medicine. Journal of Ethnopharmacology, 52, pp. 61-70.

13. Craven, H.M. and Macauley, B.J. (1992), Microorganism in pasteurized milks after refrigerated storage 3. Effect of milk processor. Australian Journal of Dairy Technology, 47 , pp. 50-55.

14. Deeth, H.C., Khusniati. T., Datta, N., and Wallace, R.B. (2002), Spoilage patterns of skim and whole milks. Journal of Dairy Research, 69, pp. 227-241.

15. Deeth, H.C., Fitz-Gerald, C.H., and Wood, A.F. (1975), A convenient method for determining the extent of lipolysis in milk. Australian Journal of Dairy Technology, 30, pp. 109-111.

16. Depree, J.A., Howard, T.M., and Savage, G.P. (1999), Flavour and pharmaceutical properties of the volatile sulphur compounds of Wasabi (Wasabia Japonica). Food Research International, 31, pp. 329-337.

17. Fitz-Gerald, C.H. and Deeth, H.C. (1983), Factors influencing lipolysis by skim milk cultures of some psychotrophic microorganisms. Australian Journal of Dairy Technology, 38, pp. 97-103.

18. Geiger, J.L. (2005), The essential oil of ginger, Zingiber officinale, and anaesthesia. International Journal of Aromatheraphy, 15, pp. 7-14.

19. Griffiths, MW. (1989), Effect of temperature and milk fat on extracellular enzyme synthesis by psychotrophic bacteria during growth in milk. Milchwissenschaft, 44, pp. 539-543.

20. Heo, J.I. (1989), Statistical evaluation, sampling and testing for downstream psychotrophic contamination on shelf life of fluid milk products. Dissertation Abstracts International B49, 10. Abs 4088.

21. Janzen, J.J., Bishop, J.R., and Bodine, A.B. (1982), Relationship of protease activity to shelf life of skim and whole milk. Journal of Dairy Science, 65, pp. 2237-2240.

22. Juffs, H.S. (1973), Identification of Pseudomonas spp. isolated from milk packed in southeast Queensland. Journal of Applied Bacteriology, 36, pp. 585-598.

23. Lopez-Fandino, R., Olano, A., Corzo, N, and Ramos, M. (1993), Proteolysis during storage of UHT milk: differences between whole and skim milk. Journal of Dairy Research, 60, pp. 339-347.

24. Ng, S.Y. (1991), Improved shelf life and quality of liquid milk products. Master of Applied Science Thesis. RMIT. Melbourne.

25. Ohta, H. and Osajima, Y. (1983), Glass capillary gas chromatographic analysis of oil components extracted from Yuzu (Citrus junos) juice. Journal of Chromatography A, 268, pp. 336-340.

26. Reinheimer, J.A, Suarez, V.B., and Haye, MA. (1993), Microbial and chemical changes in refrigerated pasteurized milk in the Santa Fe area (Argentina). Australian Journal of Dairy Technology, 48, pp. 5-9.

27. Snedecor, G.W. and Cochran, W.G. (1989), Statistical Methods, 8th Edn. Iowa State University Press. Ames, Iowa. 
28. Shipe, W.P., Basette, R., Deane, D.D., Dunkey, W.L., Hammond, E.G., Harper, W.J., Kleyn, D.H., Morgan, M.E., Nelson, J.H., and Scanlan RA. (1978), Off flavours of milk: Nomenclature, standards and bibliography. Journal of Dairy Science, 61, pp. 855-869.

29. Sorhaug, T. and Stepaniak, L. (1997), Psychrotrophs and their enzymes in milk and dairy products: Quality aspects. Review. Trends in Food Science and Technology, 8, pp. 35-41

30. Tirranen, L.S., Borodina, E.V., Ushakova, S.A., Rygalov, V.Y.E., and Gitelson, J.I. (2001), Effect of volatile metabolites of Dill, Radish and Garlic on Growth of Bacteria.. International Astronautical Federation, 49, pp. 105-108.

31. Vallejo-Cordoba, B. and Nakai, S. (1993), Using a simultaneous factor optimization approach for the detection of volatiles in milk by dynamic headspace gas chromatographic analysis. Journal of Agricultural and Food Chemistry, 41, pp. 2378-2384.

32. Wilkie, K.C.B. and Woo, S.L. (1977), A heteroxylan and hemicellulosic materials from bamboo leaves, and a reconsideration of the general nature of commonly occurring xylans and other hemicelluloses. Carbohydrate Research, 57, pp. 145-162.

33. Yamazaki, M., Makita, Y., Springob, K., and Saito, K. (2003), Regulatory mechanisms for anthocyanin biosynthesis in chemotypes of Perilla frustescens var. crispa. Biochemical Engineering Journal, 14, pp. 191-197. 